Vandecta

\title{
Kedudukan dan Kewenangan Balai Harta Peninggalan dalam Pengelolaan Harta Peninggalan Tak Terurus
}

\author{
Imaniar Putri Novianti $\bowtie$
}

Fakultas Hukum Universitas Negeri Semarang, Indonesia

Permalink/DOI http://dx.doi.org/10.15294/pandecta.v9i1.

\begin{tabular}{l} 
Info Artikel \\
\hline Sejarah Artikel: \\
Diterima December 2014 \\
Disetujui December 2014 \\
Dipublikasikan January 2015 \\
\hline
\end{tabular}

Keywords:

Heritage Hall; Heritage Not neglected; Waris

\begin{abstract}
Abstrak
Berdasarkan Pasal 1127 KUHPerdata Balai Harta Peninggalan ditugaskan menjalankan pengurusan atas setiap warisan yang tak terurus selama 30 tahun/ lebih, setelah melakukan pengelolaan sesuai batas waktu yang ditentukan dimohonkan kepada Pengadilan Negeri setempat agar harta peninggalan tak terurus tersebut ditetapkan menjadi milik negara, sehingga pengurusan harta peninggalan tak terurus yang dilakukan Balai Harta Peninggalan Semarang selesai. Dalam pelaksanaanya terdapat harta peninggalan tak terurus yang telah ditetapkan milik negara dan sampai sekarang masih dikelola oleh Balai Harta Peninggalan Semarang. Penelitian ini bertujuan untuk mengetahui dan menganalisis kedudukan dan kewenangan Balai Harta Peninggalan Semarang dalam pengelolaan harta peninggalan tak terurus serta tanggung jawab Balai Harta Peninggalan Semarang dalam pengelolaan harta peninggalan tak terurus setelah ditetapkan menjadi milik negara. Penelitian ini menggunakan jenis penelitian deskriptif analisis dengan pendekatan penelitian yuridis sosiologis. Hasil penelitian menunjukkan bahwa kedudukan dan kewenangan hukum Balai Harta Peninggalan sesuai dengan tugas pokok Balai Harta Peninggalan dan kewenangan hukum didasarkan Pasal 1127 KUHPerdata berupa penjualan dan/atau perjanjian sewa menyewa. Ditinjau dari teori kontrak, perjanjian tersebut termasuk dalam teori kehendak. Kesepakatan dalam perjanjian tersebut terjadi apabila adanya kehendak antara pihak penyewa harta peninggalan dengan Balai Harta Peninggalan Semarang untuk melakukan perjanjian yang kemudian dinyatakan ke dalam perjanjian sewa menyewa. Adapun tanggung jawab pengelolaan harta peninggalan tak terurus setelah ditetapkan menjadi milik negara tetap sama sebelum ditetapkan menjadi milik negara karena belum ada aturan yang mengaturnya sehingga masih berpedoman pada ketentuan Pasal 1127 KUHPerdata. Diperlukan peraturan mengenai tanggung jawab Balai Harta Peninggalan dalam pengelolaan harta peninggalan tak terurus setelah ditetapkan milik negara agar mendapat kepastian hukum.
\end{abstract}

\begin{abstract}
Pursuant to Article 1127 of the Civil Code Heritage Hall assigned execute the maintenance on each legacy neglected for 30 years / over, after making appropriate management of the prescribed time limit applied to the local district court neglected treasures that are set into state property, so that the maintenance of legacy slipshod carried Heritage Hall Semarang completed. In the implementation are neglected treasures that have been established stateowned and is still run by the Center for Heritage Semarang. This study aims to identify and analyze the status and authority of Heritage Hall Semarang in slipshod management of legacy and responsibility Semarang Heritage Hall in the management of neglected treasures after being set into state property. This research use descriptive research study analyzes the juridical sociological approach. The results showed that the legal position and authority Hall Heritage accordance with the basic tasks Heritage Hall and legal authority is based Section 1127 of the Civil Code in the form of the sale and / or lease agreement. Judging from the theory of the contract, the agreement is included in the theory of the will. The agreement in the agreement occurred when their wills between the tenant treasures Heritage Hall Semarang to perform the agreement later declared into the lease agreement. The responsibility for the management of legacy set to be abandoned after state remains the same before set into state property because there are no rules that govern it so it is still guided by the provisions of Article 1127 of the Civil Code. Necessary regulations on the responsibility of Heritage Hall in the management of legacy unkempt after the specified state in order to get legal certainty.
\end{abstract}




\section{Pendahuluan}

Suatu keluarga terlahir karena adanya perkawinan dan berakhir karena perceraian atau kematian. Berbicara mengenai kematian erat kaitannya dengan waris. Apabila seseorang meninggal memiliki harta kekayaan, maka yang menjadi pokok persoalan bukanlah peristiwa kematian itu, melainkan harta kekayaan yang ditinggalkan. Artinya siapakah yang berhak atas harta kekayaan yang ditinggalkan oleh almarhum dan siapakah yang wajib menanggung dan membereskan hutang- hutang almarhum jika meninggalkan hutang- hutang yang menjadi kewajibannya.

Berdasarkan Pasal 830 KUHPerdata dijelaskan bahwa pewarisan hanya berlangsung karena adanya kematian. Sehingga untuk terjadinya suatu pewarisan diperlukan 3 (tiga) unsur yaitu : pewaris, ahli waris dan harta warisan (Surini Ahlan dan Nurul Elmiah,2006:10). Dalam suatu pewarisan ada kalanya ada ahli waris yang menolak atau tidak terdapat ahli waris atau tidak diketahui ahli warisnya.

Berdasarkan Pasal 1126 KUHPerdata, jika suatu warisan terbuka, tiada seorang yang menuntutnya, ataupun apabila semua waris yang terkenal menolaknya, maka dianggaplah warisan tersebut sebagai harta peninggalan yang tak terurus dan Pasal $1127 \mathrm{KUH}-$ Perdata menjelaskan Balai Harta Peninggalan demi hukum ditugaskan menjalankan pengurusan atas setiap warisan yang tak terurus.

Pengurusan harta peninggalan tak terurus yang dilakukan Balai Harta Peninggalan dapat berupa perjanjian sewa dengan pihak penyewa harta peninggalan tak terurus dan/ atau penjualan harta peninggalan tak terurus. Namun apabila dalam pengurusan harta peninggalan tak terurus, sewaktu- waktu muncul ahli waris yang berhak atas harta peninggalan tersebut maka Balai Harta Peninggalan bertanggung jawab atas segala sesuatu yang telah diurusnya kepada ahli waris tersebut.

Balai Harta Peninggalan dalam pengurusan harta peninggalan tak terurus masih menjalankan kewenangan-kewenangan dan pengurusan sebagaimana diatur dalam KUHPerdata, hanya saja kuantitasnya menurun karena Balai Harta Peninggalan hanya bertugas mengurusi terhadap sebagian kecil golongan Warga Negara Indonesia keturunan asing dan sebagian besar hanya terhadap Warga Indonesia Keturunan Cina. Disamping itu Balai Harta Peninggalan menjalankan tugas pengurusan harta peninggalan yang tak terurus apabila adanya laporan kematian dari Dinas Kependudukan/Catatan Sipil atau masyarakat. Sehingga Balai Harta Peninggalan dalam proses pengurusan harta peninggalan tak terurus, khususnya Balai Harta Peninggalan Semarang masih sedikit karena kurangnya kesadaran hukum masyarakat akan pentingnya tugas dan wewenang Balai Harta Peninggalan. Sehingga dapat dilihat dari data sebagai berikut :

Dari diagram di atas dapat disimpulkan bahwa Balai Harta Peninggalan Semarang menjalankan pengurusan harta peninggalan tak terurus sebanyak 10 (sepuluh) budel yang terdiri dari 7 (tujuh) budel berupa barang tetap yang masih dikelola Balai Harta Peninggalan Semarang dan 3 (tiga) budel berupa barang tetap yang telah ditetapkan menjadi milik negara.

Balai Harta Peninggalan Semarang melakukan pengurusan harta peninggalan tak terurus selama 1/3 (satu pertiga) abad atau 30 (tiga puluh) tahun/ lebih. Kemudian Balai Harta Peninggalan mengajukan penghitungan penutup kepada Badan Pemeriksa Keuangan (BPK) untuk ditetapkan menjadi milik negara melalui penetapan Pengadilan Negeri. Kemudian atas perintah atau persetujuan Menteri Hukum dan Hak Asasi Manusia Republik Indonesia diserahkan kepada negara yang berupa uang tunai disetorkan ke Kas Negara, sehingga pengurusan harta peninggalan tak terurus yang dilakukan Balai Harta Peninggalan Semarang selesai. Namun dalam pelaksanaannya harta peninggalan tak terurus diserahkan kepada negara masih berupa barang tetap.

Penelitian ini difokuskan pada kedudukan dan kewenangan hukum serta tanggungjawab Balai Harta Peninggalan Semarang dalam melakukan pengelolaan harta peninggalan tak terurus setelah ditetapkan menjadi milik negara. 
Bagan 1.Pengurusan Harta Peninggalan Tak

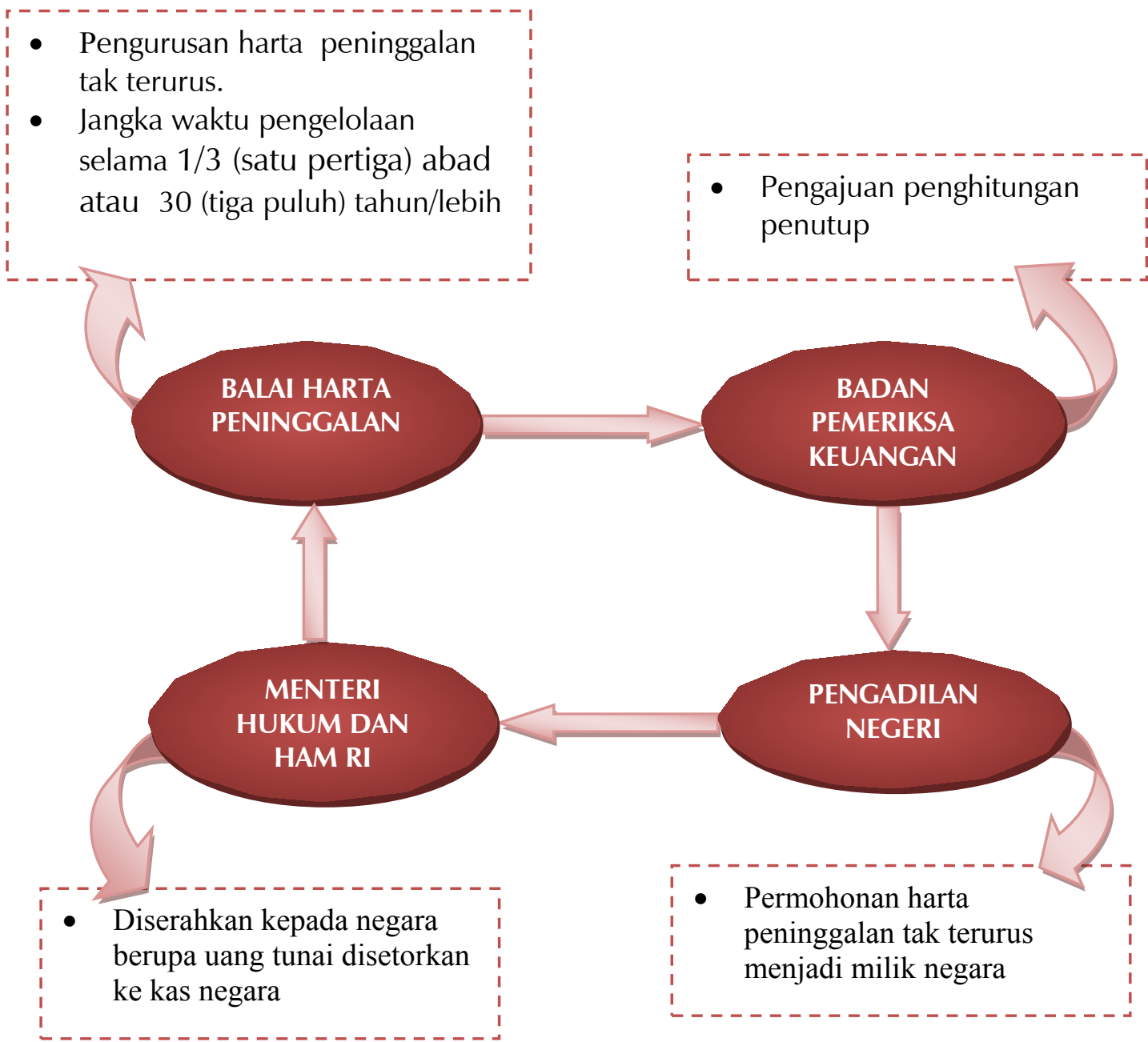

(Sumber : diolah penulis dari Standar Operasional (SOP) Balai Peninggalan Semarang)

\section{Metode Penelitian}

Jenis penelitian yang digunakan adalah deskriptif analisis. "Penelitian deskriptif analisis adalah penelitian yang diarahkan untuk memberikan gambaran atau pemaparan atas subjek dan objek penelitian sebagaimana hasil penelitian yang dilakukan peneliti" (Mukti Fajar dan Tulianto Achmad, 2010:183). Pendekatan penelitian berupa yuridis sosiologis yaitu suatu penelitian yang menitik beratkan perilaku individu atau masyarakat dalam kaitannya dalam hukum. Sumber data yang digunakan adalah sumber data primer dan sumber hukum sekunder. Sumber data primer merupakan sumber data pokok yang didapatkan melalui wawancara dengan informan dan reponden, dalam penelitian ini berasal dari Balai Harta Peninggalan sebagai obyek penelitian.

\section{Hasil Penelitian dan Pembahasan}

Di dalam hukum perdata Pasal 830 KUHPerdata pewarisan hanya berlangsung karena kematian. Menurut Surini Ahlan dan Nurul Elmiah (2006:10) terjadinya pewarisan harus memenuhi 3 (tiga) unsur pewarisan yaitu pewaris, ahli waris dan harta warisan. Ahli waris sebagai orang yang menggantikan pewarisan dalam kedudukannya terhadap harta kekayaan yang ditinggalkan pewaris dapat menerima atau menolak harta warisan tersebut. Ada pula ketika dalam proses pewarisan, ketika pewaris meninggal dunia dan meninggalkan harta kekayaan akan tetapi 
tidak diketahui ahli warisnya atau tidak ada ahli warisnya.

Apabila dalam proses pewarisan tidak diketahui ahli warisnya atau tidak ada ahli warisnya atau ahli waris menolak warisan sebagaimana diatur dalam Pasal 1045 jo. Pasal 1051 KUHPerdata, maka harta kekayaan yang ditinggalkan pewaris ketika meninggal dunia dapat dikatakan sebagai harta peninggalan tak terurus, menurut Wirjono Prodjodikoro adanya harta warisan tak terurus, apabila seseorang meninggal dunia dengan meninggalkan barang- barang miliknya, sedangkan tidak ada seorangpun yang menamakan dirinya ahli waris atau apabila semua ahli waris menolak harta warisan (Prodjodikoro,1983:192). Hal tersebut sesuai dengan ketentuan Pasal 1126 KUHPerdata "Jika suatu warisan terbuka, tiada seorangpun menuntut ataupun semua ahli waris yang dikenal menolaknya, maka dianggaplah warisan itu sebagai tak terurus" yang mana berdasarkan Pasal 1127 KUHPerdata pengelolaannya menjadi salah satu tugas Balai Harta Peninggalan.

Berbicara mengenai kedudukan hukum menurut Vankan dalam buku Kansil (1987: 44) kedudukan hukum bertujuan menjaga kepentingan tiap-tiap manusia supaya kepentingan-kepentingan itu tidak dapat diganggu, sehingga dapat diartikan mempunyai tugas untuk menjamin kepastian. Apabila dikaitkan dengan kedudukan Balai Harta peninggalan Semarang dalam pen- gelolaan harta peninggalan tak terurus erat kaitannya dengan tugas pokok Balai Harta Peninggalan yaitu sebagai wakil dari kepentingan orang- orang yang karena hukum atau keputusan hakim tidak dapat menjalankan sendiri kepentingannya berdasarkan peraturan perundang- undangan yang berlaku. Sedangkan kewenangan hukum merupakan kemampuan untuk melakukan tindakan hukum tertentu yang didasarkan pada asas legalitas (Ridwan, 2006:90). Dalam hal ini kewenangan hukum Balai Harta Peninggalan Semarang dalam pengelolaan harta peninggalan tak terurus didasarkan pada ketentuan Pasal 1127 KUHPerdata yang menjelaskan bahwa Balai Harta Peninggalan demi hukum ditugaskan menjalankan pengurusan atas setiap warisan yang tak terurus.

Balai Harta Peninggalan merupakan unit pelaksana teknis atau satuan kerja yang berada pada Kementerian Hukum dan Hak Asasi Manusia Republik Indonesia yang secara teknis berada dibawah dan bertanggung jawab kepada Direktorat Jendral Administrasi Hukum Umum melalui Direktorat Perdata. Berdasarkan Pasal 1127 KUHPerdata dijelaskan bahwa Balai Harta Peninggalan, demi hukum ditugaskan menjalankan pengurusan atas setiap warisan yang tak terurus. Berdasarkan hasil penelitian diketahui bahwa kedudukan hukum Balai Harta Peninggalan Semarang dalam pengelolaan harta peninggalan tak terurus adalah sebagai wakil dari kepentingan orang-orang yang karena hukum atau

Tabel 1. Harta Peninggalan Tak Terurus dalam Pengelolaan Balai Harta Peninggalan Semarang

\begin{tabular}{|c|c|c|c|}
\hline No & Nama Almarhum & $\begin{array}{c}\text { Tanggal meninggal } \\
\text { dunia akte kema- } \\
\text { tian }\end{array}$ & $\begin{array}{c}\text { Pengelolaan Balai Harta peninggalan } \\
\text { Semarang }\end{array}$ \\
\hline 1 & Phyppes & Tahun 1990 & Perjanjian Sewa Menyewa \\
\hline 2 & Tan Ing Tjoen & Tahun 1990 & Perjanjian Sewa Menyewa \\
\hline 3 & Theng You Wan & Tahun 1990 & Perjanjian Sewa Menyewa \\
\hline 4 & Tan Poo Kook & Tahun 1980 & Perjanjian Sewa Menyewa \\
\hline 5 & Njoo Tambah Nio & 14/2/1998 & $\begin{array}{l}\text { Penjualan Harta Peninggalan Tak ter- } \\
\text { urus }\end{array}$ \\
\hline 6 & Saputra Wigaganaputra & Tahun 2008 & Perjanjian Sewa \\
\hline 7 & MTH. Kessing & Tahun 1991 & $\begin{array}{l}\text { Penjualan Harta Peninggalan Tak ter- } \\
\text { urus }\end{array}$ \\
\hline
\end{tabular}

(Sumber: Diolah penulis dari daftar harta peninggalan tak terurus yang dalam pengurusan Balai Harta Peninggalan Semarang dalam bulan Desember 2013). 
Imaniar Putri Novianti, Kedudukan dan Kewenangan Balai Harta Peninggalan dalam Pengelolaan Harta ...

Tabel 2. Daftar harta peninggalan tak terurus yang dikelola balai harta peninggalan semarang selama 30 (tiga puluh) tahun/lebih yang diajukan menjadi milik negara

\begin{tabular}{|c|c|c|c|c|c|c|}
\hline \multirow{2}{*}{ No. } & \multirow{2}{*}{$\begin{array}{c}\text { Nama Almarhum/ } \\
\text { Tempat Tanggal } \\
\text { Meninggal }\end{array}$} & \multirow{2}{*}{$\begin{array}{l}\text { Dikelola } \\
\text { BHP }\end{array}$} & \multicolumn{2}{|c|}{ Harta/Budel } & \multirow{2}{*}{$\begin{array}{c}\text { Nama Penye- } \\
\text { wa dan Besar } \\
\text { Sewa }\end{array}$} & \multirow{2}{*}{ Keterangan } \\
\hline & & & Barang Tetap & Uang tunani & & \\
\hline 1. & $\begin{array}{l}\text { M. Brive } \\
\text { Semarang, 14-4- } \\
1946\end{array}$ & $14-4-946$ & $\begin{array}{l}\text { 7(tujuh) bangunan } \\
\text { rumah terletak di: } \\
\text { • Kp. Kledung No. } \\
360 \text { Semarang } \\
\text { • Kp. Kledung No. } \\
362 \text { Semarang } \\
\text { • Kp. Kledung No. } \\
\text { 362A Semarang } \\
\text { • Kp. Kledung No. } \\
\text { 362 B Semarang } \\
\text { • Kp. Kledung No. } \\
\text { 365 Semarang } \\
\text { •Jl. Dr. Wahidin No. } \\
\text { 80 A Semarang } \\
\text { •Jl. Kasipah No. } 5 \\
\text { Semarang }\end{array}$ & & $\begin{array}{l} \\
\text { Lie Tji- } \\
\text { ak NioRp. } \\
\text { 24.000 } \\
\text { I Bettiningsih } \\
\text { Rp. 24.000 } \\
\text { Edy Gianto } \\
\text { Rp. 24.000 } \\
\text { Yap Kiem } \\
\text { Liong Rp. } \\
\text { 24.000 } \\
\text { Lo Tjong Lam } \\
\text { Rp 24.000 } \\
\text { Agnes Seksi- } \\
\text { anawati Rp. } \\
\text { 30.000 } \\
\text { Hadi Sardjo- } \\
\text { no Rp.30.000 } \\
\end{array}$ & $\begin{array}{l}\text { *Kesemuan- } \\
\text { ya berdiri di } \\
\text { atas tanah HM } \\
\text { No.45 tertulis } \\
\text { a/n Mochamad } \\
\text { Jamin Isa } \\
60 \text { tahun } 6 \text { bu- } \\
\text { lan }\end{array}$ \\
\hline 2. & $\begin{array}{l}\text { Kluth Sarinah } \\
\text { Semarang, 02-5- } \\
1943\end{array}$ & $2-5-1943$ & $\begin{array}{l}\text { Sebuah bangunan } \\
\text { rumah berdiri di } \\
\text { atas tanah negara } \\
\text { bekas hak eigen- } \\
\text { dom verponding } \\
\text { No. } 4294 \text { terletak } \\
\text { di Kp. Grogolan No. } \\
\text { 311 Semarang }\end{array}$ & & $\begin{array}{l}\text { Philipus Nong } \\
\text { Rp. } 5.000 \\
\text { Sugiyono } \\
\text { Rp. } 5000 \\
\end{array}$ & $\begin{array}{l}\text { Masih dalam } \\
\text { proses ijin } \\
\text { pelaksanaan } \\
\text { penjualan dari } \\
\text { Menteri Hu- } \\
\text { kum dan HAM } \\
\text { RI cq. Dirjen } \\
\text { AHU } \\
63 \text { tahun } 5 \text { bu- } \\
\text { lan }\end{array}$ \\
\hline 3. & $\begin{array}{l}\text { A.A. Roden Burgh } \\
\text { Sema- } \\
\text { rang,26-3-943 }\end{array}$ & 26-3-1943 & $\begin{array}{l}\text { Sebuah bangunan } \\
\text { rumah berdiri di } \\
\text { atas tanah negara } \\
\text { bekas hak eigen- } \\
\text { dom verponding } \\
\text { No. } 3627 \text { terletak } \\
\text { di Kp. Progo II/50 } \\
\text { Semarang }\end{array}$ & & $\begin{array}{l}\text { Phoa (Tjoe) } \\
\text { Siok Nio } \\
\text { Rp. } 65.000\end{array}$ & $\begin{array}{l}\text { Masih dalam } \\
\text { proses ijin } \\
\text { pelaksanaan } \\
\text { penjualan dari } \\
\text { Menteri Hu- } \\
\text { kum dan HAM } \\
\text { RI cq. Dirjen } \\
\text { AHU } \\
64 \text { tahun } 2 \text { bu- } \\
\text { lan }\end{array}$ \\
\hline 4. & $\begin{array}{l}\text { Fleterment } \\
\text { Smith Sema- } \\
\text { rang11-11-1945 }\end{array}$ & $\begin{array}{l}14-11- \\
1945\end{array}$ & & Rp.7.747.519.59 & & $\begin{array}{l}61 \text { tahun } 5 \text { bu- } \\
\text { lan }\end{array}$ \\
\hline 5. & $\begin{array}{l}\text { Amelia Van Hall } \\
\text { Semarang, 23-5- } \\
1967\end{array}$ & $23-5-1967$ & & Rp.1.021.642.50 & & 40 tahun \\
\hline 6. & $\begin{array}{l}\text { Tan Tjoen Kie } \\
\text { Sema- } \\
\text { rang22-11-1960 }\end{array}$ & $\begin{array}{l}22-11- \\
1960\end{array}$ & & Rp.1.558.902.11 & & 47 tahun \\
\hline 7. & $\begin{array}{l}\text { Liem Nio } \\
\text { Semarang, 3-10- } \\
1973\end{array}$ & 3-10-1973 & & Rp.5.317.831.09 & & 43 tahun \\
\hline
\end{tabular}

(Sumber: Diolah penulis dari Daftar harta peninggalan tak terurus yang dikelola Balai Harta Peninggalan Semarang selama 30 (tiga puluh) tahun/lebih yang diajukan menjadi milik negara menurut keadaan tanggal 13 September 2007). 
keputusan hakim tidak dapat menjalankan sendiri kepentingannya berdasarkan peraturan perundang- undangan yang berlaku. Sedangkan kewenangan hukum Balai Harta Peninggalan Semarang berdasarkan Pasal 1127 KUHPerdata adalah menjalankan pengurusan setiap warisan yang tak terurus.

Berdasarkan hasil penelitian yang dilakukan melalui metode dokumentasi dari Balai Harta Peninggalan Semarang, terdapat harta peninggalan tak terurus dalam pengelolaan Balai Harta Peninggalan Semarang sebagai berikut:

Berdasarkan tabel di atas tentang harta peninggalan tak terurus dalam pengelolaan Balai Harta Peninggalan Semarang menunjukkan bahwa pada pokoknya Balai Harta Peninggalan Semarang khususnya dalam pengelolaan harta peninggalan tak terurus masih menjalankan kewenangan-kewenangan dan pengurusan sebagaimana diatur dalam Pasal 1127 KUHPerdata, hanya saja kuantitasnya sangat rendah karena Balai Harta PeninggalanSemarang hanya berugas mengurusi terhadap sebagian kecil golongan Warga Negara Indonesia yang menanut hukum waris Burgerlijk Wetboekyaitu:

1. Orang- orang Eropa dan mereka yang dipersamakan dengan orang Eropa;

2. Orang- orang Timur Asing Tionghoa; dan

3. Orang- orang Timur Asing lainnya, orangorang pribumi yang menundukkan diri terhadap hukum perdata barat. (Ramulyo,1993:30)

Berdasarkan standar operasional prosedur Balai Harta Peninggalan Semarang, pelaksanaan kedudukan dan kewenangan Balai Harta Peninggalan Semarang dalam pengelolaan harta peninggalan tak terurus berawal dari adanya laporan kematian dari Dinas Kependudukan/ Catatan Sipil atau masyarakat yang diajukan ke Balai Harta Peninggalan Semarang. Setelah menerima laporan kematian dari Dinas Kependudukan/Catatan Sipil tersebut Balai Harta Peninggalan Semarang, melalui Anggota Teknis Hukum dibantu dengan Seksi harta peninggalan wilayah I/II/III melakukan pemanggilan kepada ahli waris/ keluarga dengan membawa bukti-bukti yang sah dan memanggil para kreditur/debitur.
Berita acara penghadapan dibuat setelah pihak-pihak yang dipanggil atau penyewa harta peninggalan tak terurus datang menghadap Balai Harta Peninggalan Semarang. Setelah dibuat berita acara penghadapan, Balai Harta Peninggalan melakukan inventarisasi atau pencatatan harta peninggalan. Tujuan dari inventarisasi itu sendiri untuk mengetahui harta kekayaan apa saja yang ditinggalkan dan mengetahui hutang-hutang dan beban-beban yang ditinggalkan pewaris. Setelah dilakukan inventarisasi Balai Harta Peninggalan mengumumkan melalui iklan pada surat kabar dan Berita Negara dan pemberitahuan kepada Kejaksaan Negeri setempat.

Berdasarkan Pasal 1128 ayat (1) KUHPerdata dijelaskan bahwa Balai Harta Peninggalan, ketika mulai mengurus harta warisan itu, harus menyegel barang- barang warisan, kemudian mengadakan perincian dari barang-barang itu, selanjutnya mengurus barang-barang itu dan menyelesaikannya. Balai Harta Peninggalan juga diwajibkan memanggil para ahli waris yang ada, dengan melakukan panggilan-panggilan umum yang dimuat dalam surat-surat kabar, dan dengan dengan cara-cara lain yang dianggap layak (Pasal 1128 ayat (2) KUHPerdata).

Dalam melaksanakan kedudukan dan kewenangan Balai Harta Peninggalan Semarang dalam pengelolaan harta peninggalan tak terurus dapat dilakukan dengan melakukan perjanjian sewa menyewa dengan penyewa harta peninggalan tak terurus atau menjual harta peninggalan tak terurus.

Pelaksanaan perjanjian sewa harta peninggalan tak terurus dilakukan dengan cara calon penyewa harta peninggalan tak terurus melakukan perjanjian sewa dengan Balai Harta Peninggalan Semarang. Perjanjian yang dibuat antara Balai Harta Peninggalan dan penyewa mengikat kedua belah pihak dan dijadikan sebagai dasar hukum dalam melaksanakan perjanjian.

Balai Harta Peninggalan Semarang selain memiliki kewenangan untuk melakukan perjanjian sewa menyewa, dalam pengelolaan harta peninggalan tak terurus juga dapat dilakukan dengan cara menjual harta peninggalan tak terurus. Berdasarkan 
Bagan 2. Prosedur Pengelolaan Harta Peninggalan Tak Terurus Yang Dilakukan Balai Harta Peninggalan Semarang
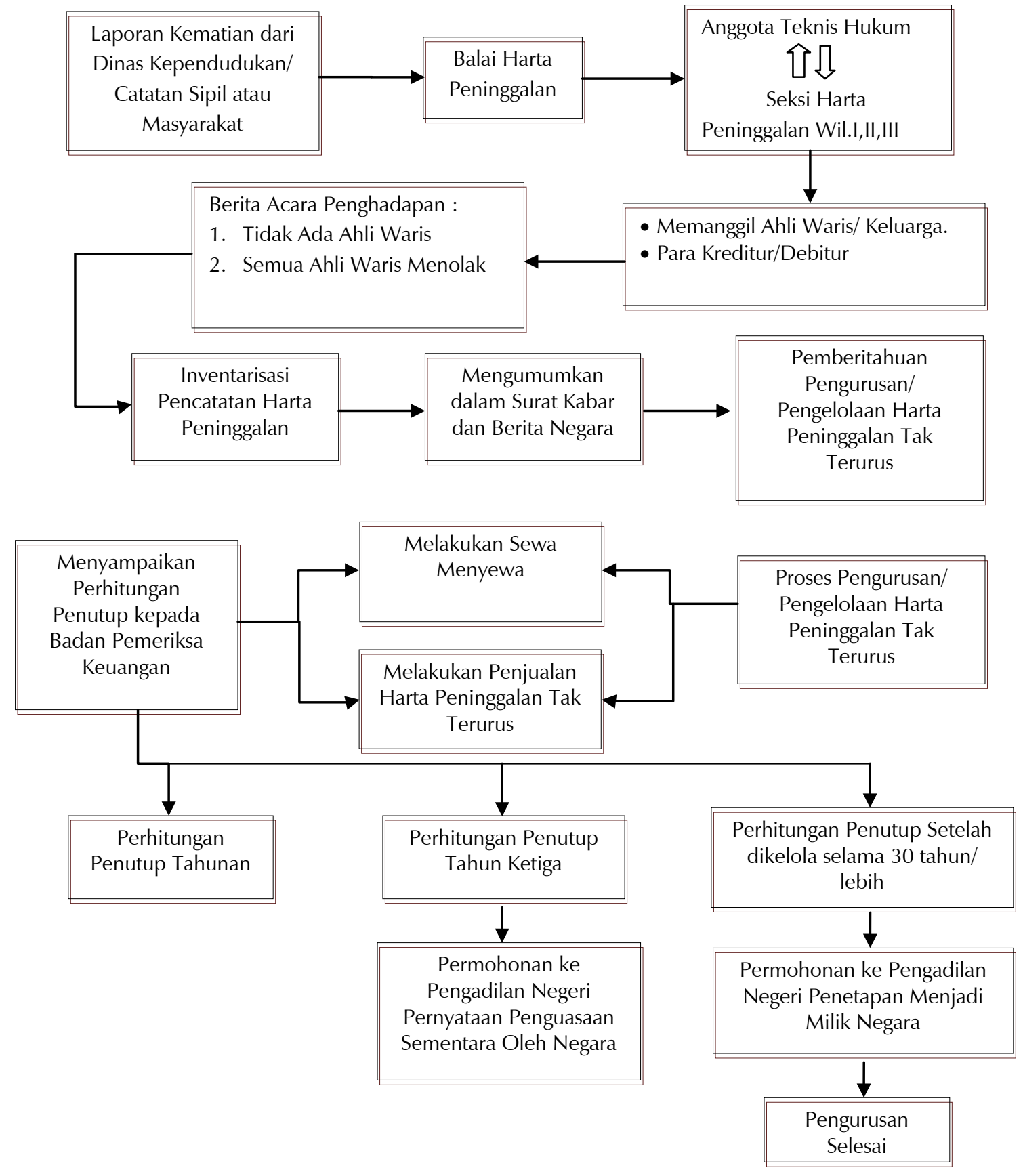

(Sumber: Pengolahan data yang dilakukan oleh peneliti berdasarkan Standar oprasional Balai Harta Peninggalan pada tahun 2014)

Peraturan Menteri Hukum dan Hak Asasi Manusia Republik Indonesia Nomor M.02HT.05.10 Tahun 2005 tentang permohonan ijin pelaksanaan penjualan harta kekayaan yang pemiliknya dinyatakan tidak hadir dan harta peninggalan yang tidak terurus yang berada dalam pengurusan dan pengawasan
Balai Harta Peninggalan Penjualan harta peninggalan tak terurus dilakukan dengan cara penyewa harta peninggalan tak terurus mengajukan permohonan untuk membeli harta peninggalan tak terurus kepada Balai Harta peninggalan. Setelah menerima permohonan membeli, Balai Harta Peninggalan melaku- 
Bagan 3. Prosedur Perjanjian Sewa

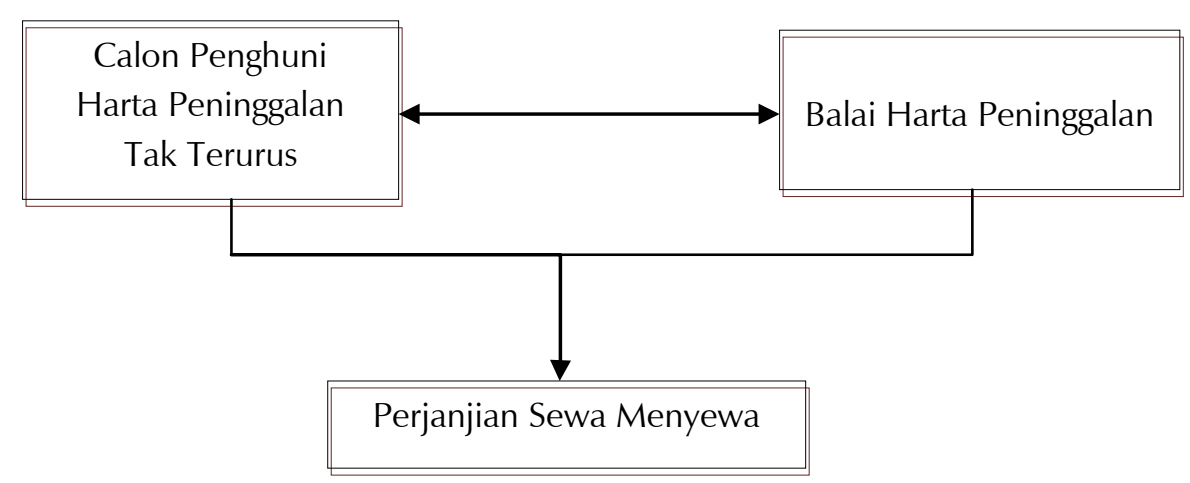

(Sumber: Pengolahan data yang dilakukan oleh peneliti berdasarkan Standar oprasional Balai Harta Peninggalan pada tahun 2014)

kan pemeriksaan setempat untuk mengetahui kebenaran formil dan material atas harta peninggalan tak terurus. Kemudian Balai Harta peninggalan mengajukan permohonan ijin prinsip untuk menjual harta peninggalan tak terurus kepada Menteri Hukum dan Hak Asasi Manusia Republik Indonesia cq. Direktur Jendral yang pada pokoknya menyampaikan permohonan membeli harta peninggalan tak terurus dari penyewa harta peninggalan tak terurus dengan disertai:

1. Fotocopy akta kematian dilegalisir notaris;

2. Fotocopy berita acara pencatatan harta;

3. Fotocopy surat pemberitahuan kepada Kejaksaan Negeri dan badan pemeriksa keuangan;

4. Fotocopy pengumuman pemanggilan ahli waris/ pihak yang berkepentingan dalam berita negara dan surat kabar;

5. Fotocopy surat bukti penghuni;

6. Fotocopy perjanjian sewa menyewa;

7. Fotocopy tanda bukti sewa menyewa;

8. Fotocopy surat permohonan membeli dari penghuni.

Setelah menerima surat permohonan ijin prinsip menjual rumah dari Balai Harta Peninggalan, Kementrian Hukum dan Hak Asasi Manusia Republik Indonesia cq. Direktur Jendral membentuk tim bersama dengan Inspektorat Jendral untuk melakukan pemeriksaan setempat guna mengetahui kebenaran formal dan material atas permohonan Balai Harta Peninggalan. Pemeriksaan setempat dilakukan paling lambat tiga bulan terhitung sejak surat permohonan ijin prinsip menjual rumah dari Balai Harta Peninggalan. Setelah dilakukan pemeriksaan setempat oleh Direktur Jendral, Direktur Jendral memberikan persetujuan permohonan izin prinsip untuk menjual harta peninggalan tak terurus dan memerintahkan mengajukan permohonan ijin menjual harta peninggalan tak terurus kepada Pengadilan Negeri setempat dan sekaligus mengusulkan pembentukan panitia penaksir guna menentukan harga penjualan kepada Balai Harta Peninggalan Semarang.

Setelah menerima surat persetujuan permohonan izin prinsip untuk menjual harta peninggalan tak terurus dari Direktur Jendral, Balai Harta Peninggalan Semarang mengajukan permohonan ijin menjual harta peninggalan tak terurus kepada Pengadilan Negeri setempat dan sekaligus mengusulkan pembentukan Panitia Penaksir guna menentukan harga penjualan. Kemudian Pengadilan Negeri setempat memberikan penetapan ijin menjual harta peninggalan tak terurus kepada Balai Harta Peninggalan Semarang dan menentukan panitia taksir terdiri dari 4 (empat) orang yaitu Panitera Pengadilan Negeri, Anggota Teknis Hukum Balai Harta Peninggalan Semarang, Badan Pertanahan Nasional dan DPU Cipta Karya.

Tim Penaksir yang sudah dibentuk oleh Pengadilan Negeri melakukan penaksiran atas harta peninggalan tak terurus dan menyampaikan permohonan ijin pelaksanaan penjualan harta peninggalan tak terurus yang pada pokoknya memberitahukan penetapan 
ijin menjual dan berita acara penaksiran kepada Menteri Hukum dan Hak Asasi Manusia Republik Indonesiacq. Direktur Jendral.

Setelah menerima permohonan ijin pelaksanaan penjualan harta peninggalan tak terurus Menteri Hukum dan Hak Asasi Manusia Republik Indonesiacq. Direktur Jend- ral. Menilai harga taksiran yang ditentukan oleh panitia penaksir. Apabila dalam penaksiran tersebut dirasa tidak wajar maka dapat dilakukan penaksiran ulang oleh tim penaksir. Penaksiran ulang dilakukan oleh tim penaksir paling lambat 3 (tiga) bulan terhitung sejak Direktur Jendral menetapkan harga

\section{Bagan 4. Prosedur Penjualan Harta Peninggalan Tak Terurus}

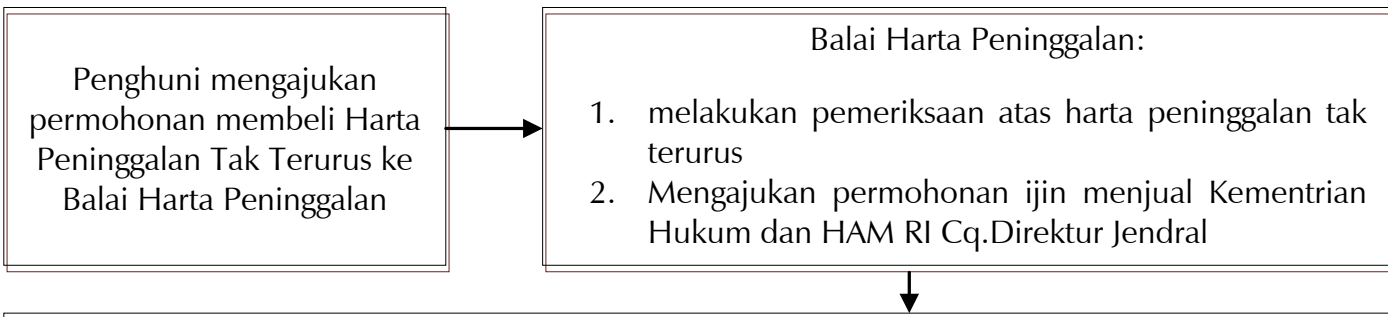

1. Fotocopy akta kematian dilegalisir notaris.

2. Fotocopy berita acara pencatatan harta

3. Fotocopy surat pemberitahuan kepada Kejaksaan Negeri dan badan pemeriksa keuangan

4. Fotocopy pengumuman pemanggilan ahli waris/ pihak yang berkepentingan dalam berita negara dan surat kabar

5. Fotocopy surat bukti penghuni

6. Fotocopy perjanjian sewa menyewa

7. Fotocopy tanda bukti sewa menyewa

Kementrian Hukum dan HAM RI Cq.Direktur Jendral :

1. Pemeriksaan Setempat oleh Direktorat Jendral

2. Persetujuan permohonan ijin prinsip untuk menjual harta peninggalan tak terurus

\section{Balai Harta Peninggalan:}

1. Mengajukan permohonan ijin pelaksanaan penjualan

2. Melaporkan Berita Acara Penaksiran dan Penetapan Ijin Menjual kepada Kementrian Hukum dan HAM RI cq. Direktur Jendral

\section{$\longrightarrow$}

Balai harta Peninggalan: Mengajukan permohonan ijin menjual dan mengusulkan penunjukan panitia penaksir kepada Pengadilan Negeri

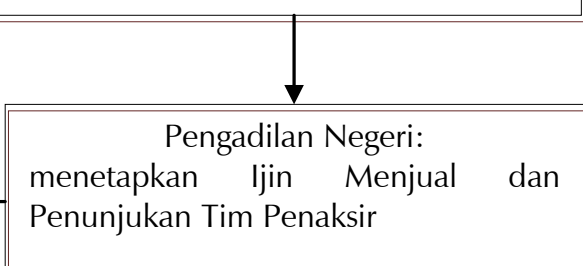

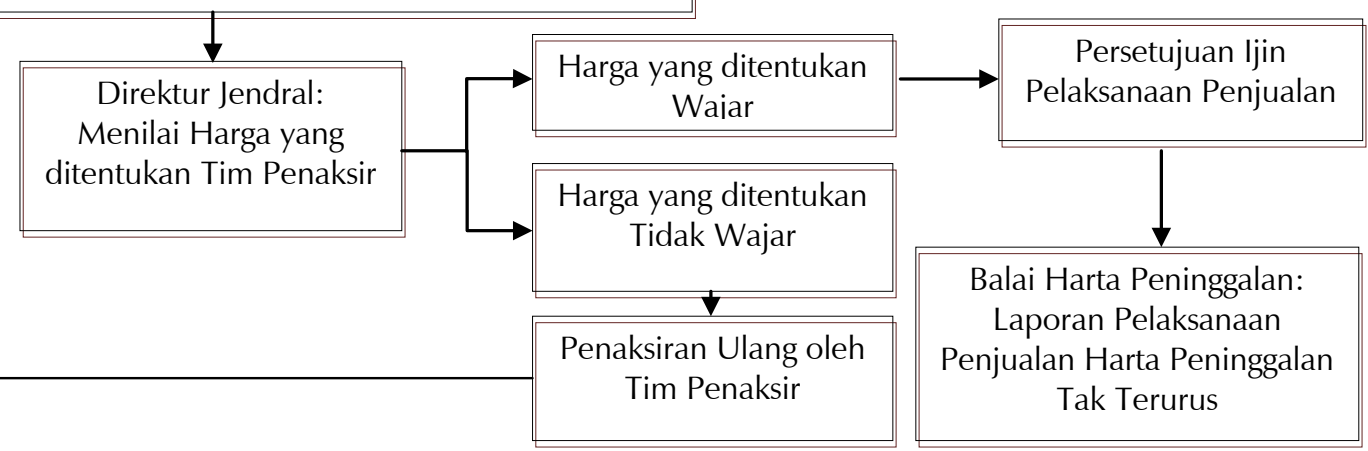

(Sumber: Pengolahan data yang dilakukan oleh peneliti berdasarkan Standar oprasional Balai Harta Peninggalan pada tahun 2014) 
yang ditentukan oleh panitia penaksir tidak wajar. Apabila dalam penaksiran tersebut dirasa wajar maka Direktur Jendral memberikan ijin pelaksanaan penjualan kepada Balai Harta Peninggalan Semarang.

Ijin pelaksanaan penjualan yang diberikan kepada Balai Harta Peninggalan Semarang harus sudah dilaksanakan dalam jangka waktu paling lambat 6 (enam) bulan sejak diterimanya ijin pelaksanaan penjualan dan Balai Harta Peninggalan Semarang wajib melaporkan pelaksanaan penjualan kepada Direktorat Jendral dengan melampirkan bukti kuwitansi pembayaran dalam jangka waktu paling lambat 1 (satu) bulan setelah pelaksanaan penjualan harta peninggalan tak terurus.

Berdasarkan Pasal 1129 KUHPerdata jika setelah mulai hari terbukannya warisan tidak seorangpun memajukan diri maka Negara akan berkuasa sementara menguasai harta peninggalan. Berdasarkan hasil wawancara dengan salah satu anggota Teknis Hukum Balai Harta Peninggalan Semarang, apabila selama Balai Harta Peninggalan Semarang melakukan pengelolaan atas harta peninggalan tak terurus ada ahli waris dari pewaris yang meninggalkan harta peninggalan tak terurus hadir maka ahli waris tersebut harus membuktikannya.

Balai Harta peninggalan Semarang dalam pengelolaan harta peninggalan tak terurus memperoleh hasil penjualan atau hasil sewa atas harta kekayaan yang tak terurus yang berada dalam pengurusan dan pengawasan Balai Harta Peninggalan Semarang. Uang hasil pengelolaan harta peninggalan tak terurus baik hasil perjanjian sewa menyewa maupun hasil penjualan harta peninggalan tak terurus, disimpan dalam bentuk deposito pada Bank Pemerintah selama 1 (satu) tahun dan setelah jatuh tempo diperpanjang untuk jangka waktu 1 (satu) tahun dan seterusnya sampai 1/3 (satu pertiga) abad atau selama 30 (tiga puluh) tahun. Kemudian Balai Harta Peninggalan Semarang harus menyerahkan uang pihak ketiga tersebut menjadi milik negara (ke kas negara).

Hal tersebut sesuai dengan dasar hukum penyerahan uang pihak ketiga yang dikelola Balai Harta Peninggalan Semarang menjadi milik negara adalah Ketentuan Pasal 73 Intruksi Untuk Balai- Balai Harta Peniggalan di Indonesia (Ordonantie tanggal Oktober 1972 No. 166) jo. Intruksi Menteri Kehakiman Republik Indonesia Nomor M.05. UM.01.06 tahun 1984 tanggal 10 September 1984 tentang Penertiban dan Pengurusan Harta Kekayaan Yang Dikelola oleh Balai Harta Peninggalan mengalihkan harta kekayaan milik pihak ketiga yang dikelola selama lebih dari 1/3 (satu pertiga) abad menjadi milik negara. Apabila harta kekayaan pihak ketiga tersebut berupa uang tunai, maka penyerahannya dilakukan dengan caramenyetorkan ke kas negara dengan terlebih dahulu mengajukan persetujuan Menteri Hukum dan Hak Asasi Manusia Republik Indonesia untuk diajukan ke Pengadilan Negeri.

Balai Harta Peninggalan Semarang dalam melakukan pengelolaan Harta Peninggalan tak terurus setelah ditetapkan menjadi milik negara masih tetap melakukan pengelolaan harta peninggalan tak terurus tersebut baik berupa perjanjian sewa menyewa dan dimungkinkan untuk melakukan penjualan harta peninggalan tak terurus tersebut bagi pihak yang berkeinginan untuk membeli karena masih dalam proses ijin pelaksanaan penjualan dari Menteri Hukum dan Hak Asasi Manusia Republik Indonesia cq. Direktur Jendral Administrasi Hukum Umum.

Balai Harta Peninggalan Semarang dalam melakukan pengelolaan harta peninggalan tak terurus setelah ditetapkan menjadi milik negara tetap berpedoman pada ketentuan Pasal 1127 KUHPerdata hal tersebut sesuai dengan ketentuan Pasal II Aturan Peralihan UUD 1945 untuk mengisi kekosongan hukum,segala peraturan perundang- undangan masih tetap berlaku selama belum diadakan yang baru.

\section{Simpulan}

Kedudukan dan kewenangan hukum Balai Harta Peninggalan Semarang dalam pengelolaan harta peninggalan tak terurus adalah sebagai wakil dari kepentingan orangorang yang tidak dapat menjalankan sendiri kepentingannya. Hal ini didasarkan pada ketentuan Pasal 1127 KUHPerdata untuk men- 
gurus warisan yang tak terurus. Balai Harta Peninggalan Semarang berwenang untuk melakukan penjualan harta peninggalan dan/ atau melakukan perjanjian sewa menyewa.

Saran yang dapat diberikan adalah perlunya dibentuk peraturan yang mengatur mengenai tanggung jawab Balai Harta Peninggalan dalam pengelolaan harta peninggalan tak terurus baik sebelum maupun setelah ditetapkan menjadi milik negara sehingga dalam melaksanakan kedudukan dan kewenagan hukum Balai Harta Peninggalan mendapat kepastian hukum.

\section{Daftar Pustaka}

Surini Ahlan Sjarif dan Nurul Elmiyah. 2006. Hukum Kewarisan Perdata Barat. Jakarta: Kencana;

Fajar ND, Mukti dan Yulianto Achmad. 2010. Dualisme Penelitian Hukum Normatif \& Empiris. Jakarta: Pustaka Pelajar;

Prodjodikoro, Wirjono. 1983. Hukum Warisan Di Indonesia. Jakarta: Sumur Bandung;

Kansil.1987. Pengantar Ilmu Hukum Dan Tata Hukum Indonesia. Jakarta: Balai Pustaka;

Ramulyo, Mohd. Idris .1993. Beberapa Masalah Pelaksanaan Hukum Kewarisan Perdata Barat (Burgerlijk Wetboek). Jakarta: Sinar Grafika;

Ridwan HR. 2006. Hukum Administrasi Negara. Jakarta: PT Raja grafindo Persada;

Kitab Undang-Undang Hukum Perdata 